\title{
Inhibition of Influenza Virus Replication by Nitric Oxide
}

\author{
GUUS F. RIMMELZWAAN,* MARIANNE M. J. W. BAARS, PIM DE LIJSTER, \\ RON A. M. FOUCHIER, AND ALBERT D. M. E. OSTERHAUS \\ National Influenza Center, Department of Virology, Erasmus University Rotterdam, 3000 DR Rotterdam, The Netherlands
}

Received 5 March 1999/Accepted 2 July 1999

\begin{abstract}
Nitric oxide (NO) has been shown to contribute to the pathogenesis of influenza virus-induced pneumonia in mouse models. Here we show that replication of influenza A and B viruses in Mabin Darby canine kidney cells is severely impaired by the NO donor, $S$-nitroso- $N$-acetylpenicillamine. Reduction of productively infected cells and virus production proved to correlate with inhibition of viral RNA synthesis, indicating that NO affects an early step in the replication cycle of influenza viruses.
\end{abstract}

Nitric oxide (NO), a gaseous free radical has been shown to have multiple biological functions. NO is catalytically generated by one of the three isoforms of NO synthase (NOS) from L-arginine. eNOS and nNOS, which are produced in endothelial cells and neuronal cells, have been shown to play a role in vasodilatation and neurotransmission, respectively, whereas NO generated by iNOS (NOS2), the inducible form of NOS, has been shown to play a role in the defense against a variety of microbial pathogens, including bacteria, parasites (for a review, see reference 24), and viruses, including herpes simplex virus type 1 (HSV-1), vesicular stomatitis virus, Japanese encephalitis virus, poliovirus, murine hepatitis virus, murine leukemia virus, coxsackievirus, ectromelia virus, rhinovirus, and vaccinia virus $(3,5,6,11,15,19,20,29,31,37)$.

Although the mode of action of NO is not fully understood, it has been shown that NO can affect the function of iron- and thiol-containing proteins $(18,25,28)$, such as guanylate cyclase, ribonucleotide reductase, aconitase, and mitochondrial electron transport enzymes (22). iNOS can be induced in a number of different cell types by cytokines or bacterial products. It has been demonstrated that iNOS is expressed in murine macrophages (36), mouse T cells (35), human hepatocytes (7), alveolar macrophages (26), and mononuclear cells (33). NO can also be released from human airway epithelial cells, the primary target for influenza viruses, after stimulation with gamma interferon, interleukin $1 \beta$ (IL-1 $\beta$ ), and tumor necrosis factor alpha $(\mathrm{TNF}-\alpha)(4,10,32)$. Interestingly, the production of these cytokines is induced shortly after infection with influenza viruses $(12,13,34)$. Furthermore, it has been demonstrated that the expression of the hemagglutinin (HA) of influenza viruses can activate $\mathrm{NF}-\kappa \mathrm{B}$, a transcription factor which has been shown to regulate the expression of a number of cytokine genes, including the TNF- $\alpha$ and IL-1 $\beta$ genes (27).

Although studies in mouse models have indicated that the release of NO after infection with influenza viruses also contributes to the pathogenesis of influenza virus-induced pneumonia, it may be argued that the production of NO in the respiratory tract may also provide a first-line defense mechanism against influenza viruses. Since to date it is not known whether influenza virus replication is sensitive to the action of NO, we studied the effect of $S$-nitroso- $N$-acetylpenicillamine (SNAP) on influenza replication in vitro. SNAP is the nitrosy-

\footnotetext{
* Corresponding author. Mailing address: National Influenza Center, Department of Virology, Erasmus University Rotterdam, P.O. Box 1738, 3000 DR Rotterdam, The Netherlands. Phone: 31104088066. Fax: 3110 4089485. E-mail: rimmelzwaan@viro.fgg.eur.nl.
}

lated form of L-acetylpenicillamine and immediately donates NO when added to culture medium (14).

Mabin Darby canine kidney (MDCK) cells were infected at different multiplicities of infection (MOI) with influenza vi-

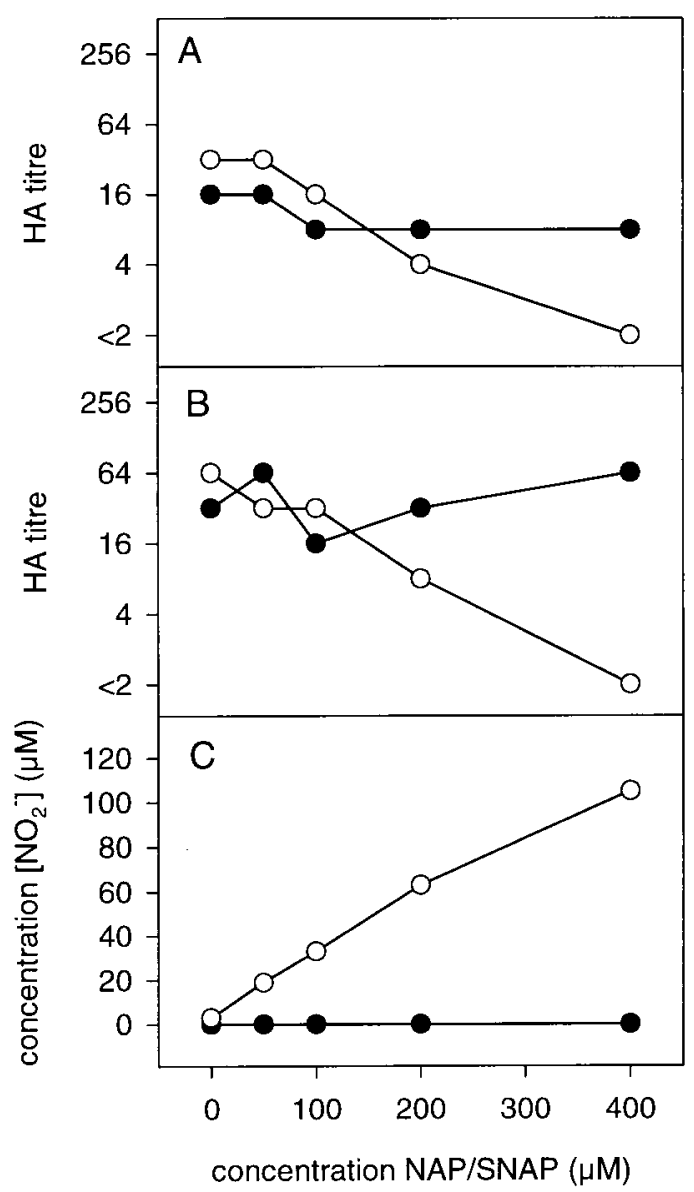

FIG. 1. Addition of the NO donor SNAP inhibits the replication of influenza $\mathrm{A}$ and $\mathrm{B}$ viruses in a dose-dependent manner. MDCK cells were infected with influenza virus A/Netherlands/202/95 at an MOI of 0.3 (A). The culture supernatants were assayed for hemagglutination activity $24 \mathrm{~h}$ postinfection. MDCK cells were also infected with influenza virus B/Netherlands/22/95 with an MOI of 0.03 (B). The culture supernatants were analyzed for HA $48 \mathrm{~h}$ postinfection. Using Griess reagent, the release of NO from SNAP was demonstrated by detection of its metabolite nitrite (C). The infected cells were treated with the indicated concentrations of SNAP $(O)$ or NAP $(\bullet)$. 


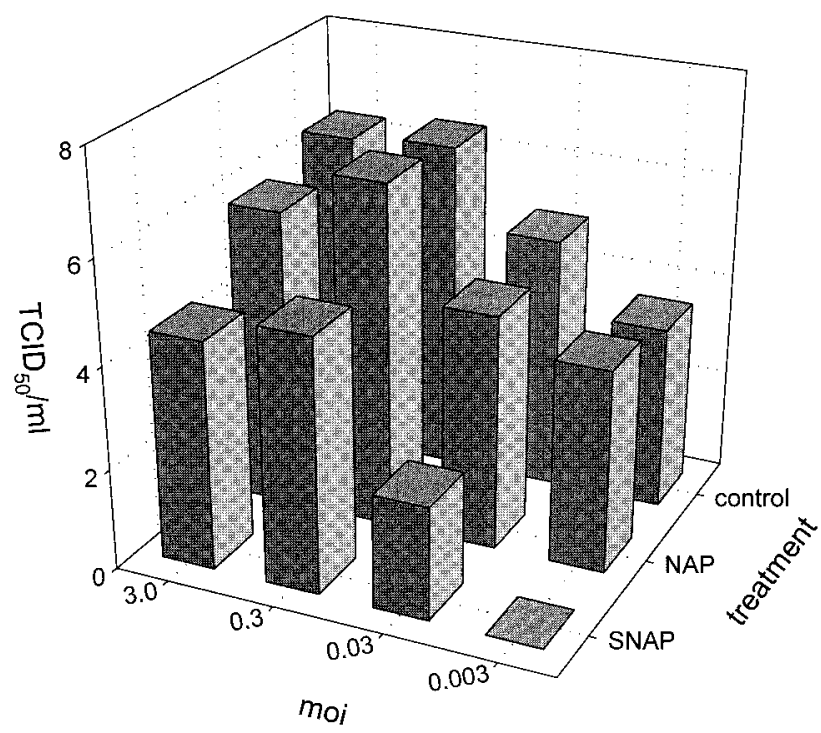

FIG. 2. The addition of the NO donor SNAP inhibits the release of infectious virus into the culture supernatant. MDCK cells were infected with influenza virus A/Netherlands/202/95 at the indicated MOI and subsequently treated with 400 $\mu \mathrm{M}$ SNAP or NAP or left untreated. The measurement of infectious virus in culture supernatants of the cells was performed by limiting dilution analysis and expressed as $50 \%$ tissue culture infective doses per milliliter $\left(\mathrm{TCID}_{50} / \mathrm{ml}\right)$ as previously described (30). ruses and immediately after infection were treated with different doses of SNAP or a control molecule which lacks the NO-donating $S$-nitroso group, $N$-acetylpenicillamine (NAP). SNAP and NAP were added in a dose range which was found to inhibit the replication of other viruses $(3,5,15,19,29)$. The experiments were performed twice and the results of representative experiments are shown in Fig. 1 and 2. SNAP inhibited the replication of both influenza A (A/Netherlands/202/95 [H3N2]) and influenza B (B/Netherlands/22/95) viruses in a dose-dependent fashion as shown by measuring the HA titers released in the culture supernatants of infected cells (Fig. 1). The observed inhibitory effects correlated with the release of $\mathrm{NO}_{2}{ }^{-}$, an intermediate metabolite of $\mathrm{NO}$, in the culture medium, as determined with Griess reagent (8). The strongest inhibition was observed by using SNAP at a concentration of $400 \mu \mathrm{M}$. The reduction of HA titer also correlated with a reduction of the release of infectious virus into the culture supernatants of MDCK cells infected with influenza virus A/Netherlands/202/95 (Fig. 2). Twenty-four hours postinfection, the inhibitory effect of NO was most pronounced using a low MOI for the infection of the MDCK cells. The addition of SNAP to the cultures did not affect the viability of MDCK cells as determined by the trypan blue exclusion method, and the replication of the MDCK cells was slightly reduced. The cell number in untreated cultures increased from $2.1 \times 10^{6}$ to $2.9 \times$ $10^{6}$ per well in $24 \mathrm{~h}$, while in the presence of $400 \mu \mathrm{M}$ SNAP, the increase was from $1.7 \times 10^{6}$ to $2.1 \times 10^{6}$. Neuraminidase

\section{SNAP/NAP added at}

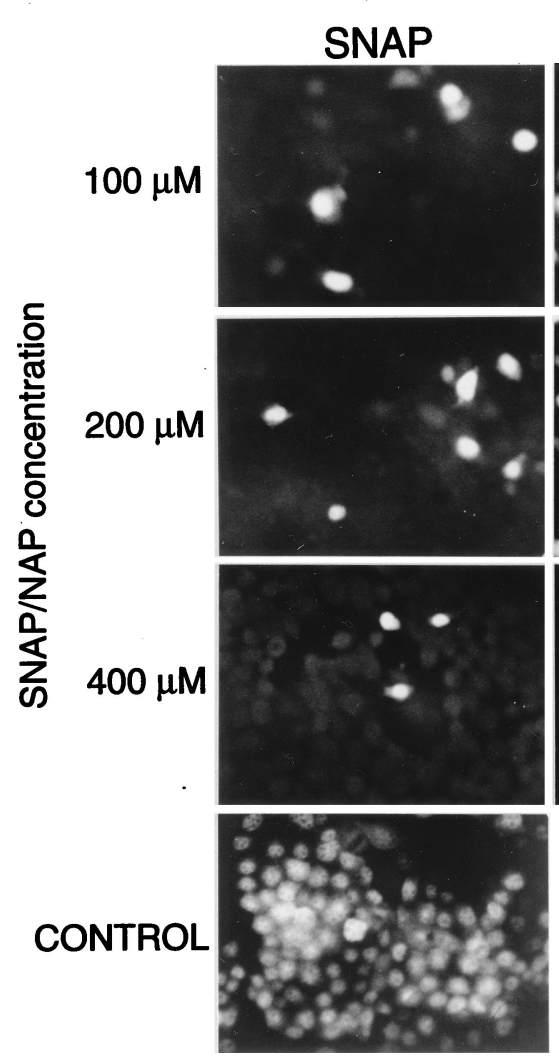

1 hour post infection

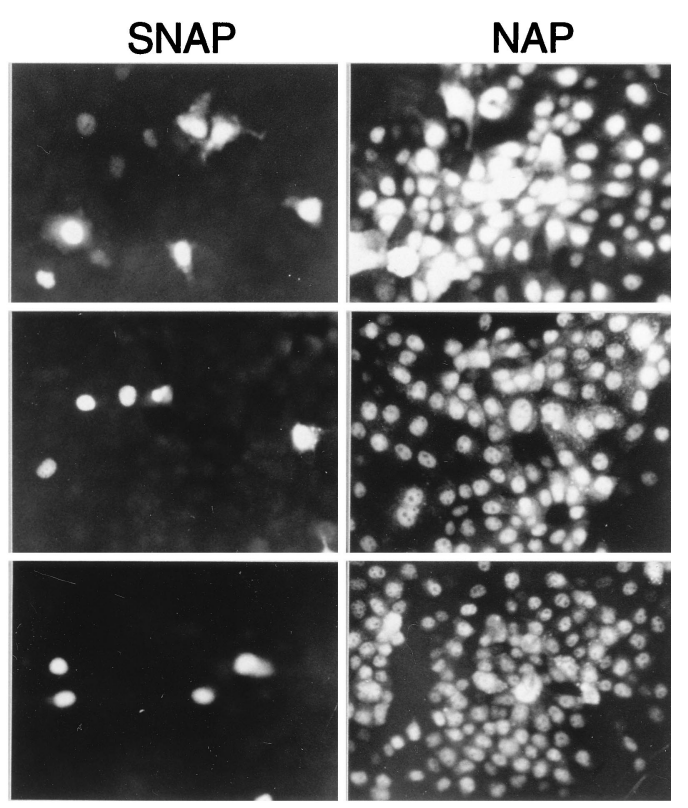

FIG. 3. The number of influenza virus-infected MDCK cells is affected by the addition of SNAP to the cultures before or after infection. SNAP or NAP was added at the indicated concentrations $3 \mathrm{~h}$ before infection or $1 \mathrm{~h}$ after infection of the cells with influenza virus A/Netherlands/18/94 at an MOI of 1.0. Twelve hours postinfection, the cells were fixed with acetone and incubated with a monoclonal antibody specific for the nucleoprotein. 

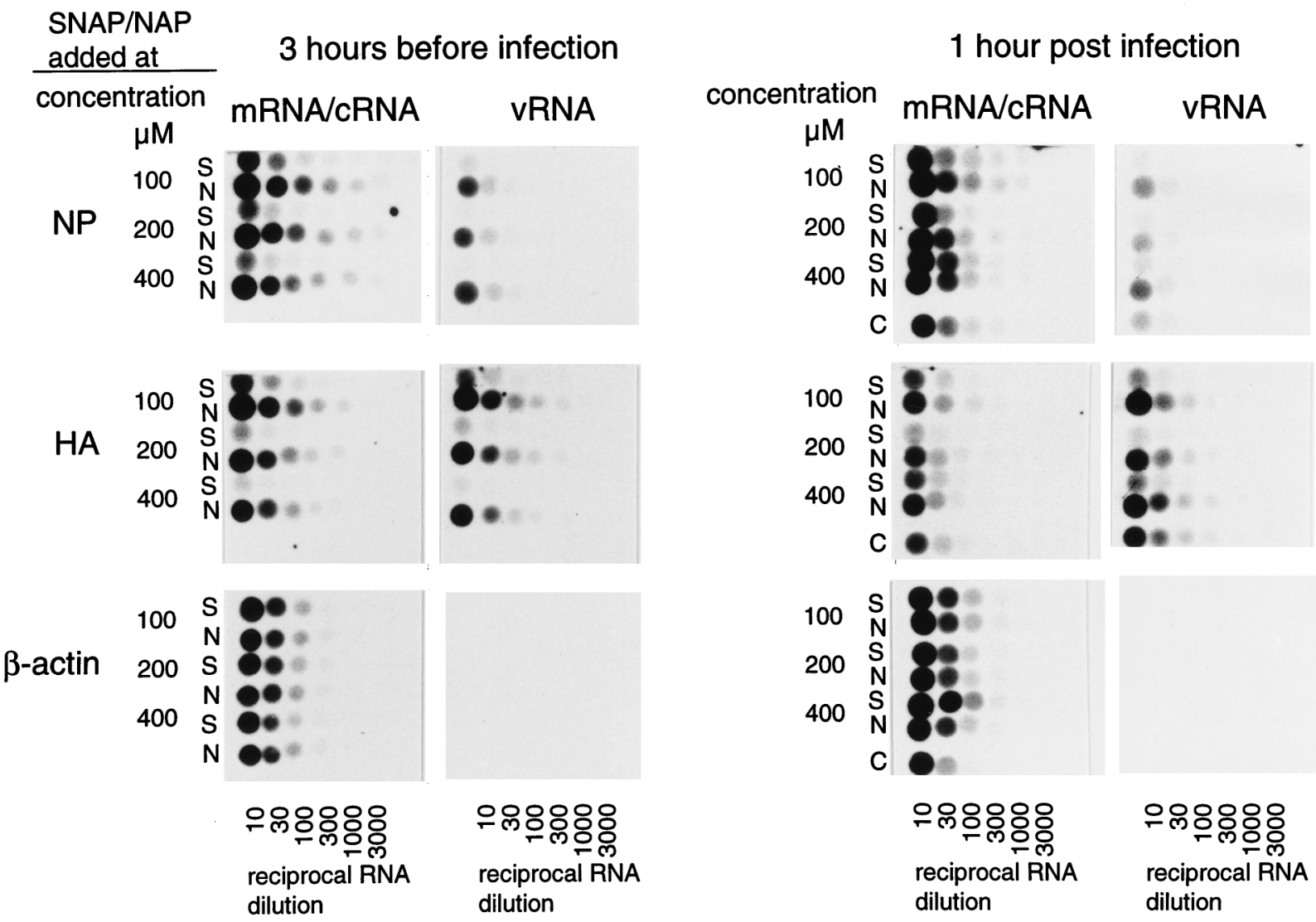

FIG. 4. The synthesis of virus-specific positive strand (mRNA and cRNA) and negative strand (vRNA) is impaired by the addition of SNAP to the cultures. SNAP $(\mathrm{S})$ or NAP $(\mathrm{N})$ was added to the cultures at the indicated concentrations $3 \mathrm{~h}$ before or immediately after infection with influenza virus A/Netherlands/18/94. Untreated cultures were included as controls (C). MDCK cells were infected at an MOI of 1.0 and RNA was extracted $12 \mathrm{~h}$ postinfection. Threefold serial dilutions of the RNA preparations were transferred to the membranes and subsequently hybridized to DIG-labelled RNA probes specific for positive-sense HA or NP mRNA/cRNA, negative-sense HA and NP vRNA, and positive-sense $\beta$-actin RNA, which was included as a control for cellular mRNA, as described previously (30).

and hemagglutination activities were also not affected by the direct addition of SNAP to the virus preparations (data not shown). In addition to SNAP, the effect of two other NOdonating molecules, sodium nitroprusside (SNP) and 3-morpholinosydnonimine (SIN-1), was also tested. It was found that SNP and SIN-1 inhibited replication of influenza virus A/Netherlands/18/94 (H3N2) at a concentration of $100 \mu \mathrm{M}$, which was found to be inhibitory for the replication of other viruses (3), confirming the inhibitory effect of NO.

This inhibitory effect of NO on influenza virus replication was further demonstrated by analyzing influenza virus-infected cells in an immunofluorescence assay using monoclonal antibodies specific for the nucleoprotein (Imagen A and B; Dakopats) and in RNA hybridization assays (30). To this end, MDCK cells were infected with influenza virus A/Netherlands/ 18/94 (H3N2) at an MOI of 1.0 and treated with different doses of SNAP or NAP immediately after or $3 \mathrm{~h}$ prior to infection. Compared with untreated control cultures, the number of infected cells was clearly reduced in SNAP treated cultures, but not in cultures treated with NAP (Fig. 3). The inhibition of hemagglutination activity and the release of infectious virus in the supernatants of these cultures by the addition of SNAP paralleled the inhibition observed with influenza virus A/Netherlands/202/95 in the experiments described above (data not shown).

To identify which step in the replication cycle of influenza virus was inhibited, the synthesis of vRNA and mRNA encod- ing the proteins HA and NP was monitored in parallel by an RNA hybridization assay using digoxigenin (DIG)-labelled RNA probes specific for negative- and positive-sense HA and NP RNA molecules and $\beta$-actin mRNA. The latter probe was transcribed from the pBluescript plasmid containing the $\beta$-actin coding sequence (9), as described previously (30). The addition of the NO donor $3 \mathrm{~h}$ prior to infection significantly reduced the synthesis of both vRNA and mRNA (Fig. 4). When SNAP was added $1 \mathrm{~h}$ postinfection, inhibition of RNA synthesis was also observed, although it was less pronounced. Levels of $\beta$-actin mRNA were not significantly affected by the addition of SNAP, indicating that the transcriptional activity and mRNA stability of the MDCK cells were not influenced by NO.

Taken together, the data presented demonstrate that NO inhibits the replication of influenza viruses, probably during the early steps of the virus replication cycle, involving the synthesis of vRNA and mRNA encoding viral proteins. Therefore we hypothesize that the production of NO by iNOS in airway epithelial cells, induced by cytokines which are known to be synthesized shortly after infection with influenza viruses by NK cells and macrophages $(12,13)$, provides an antiviral effect in these cells. This mechanism would reduce primary replication of influenza viruses before other effector mechanisms of the immune system, such as those mediated by B and $\mathrm{T}$ lymphocytes, are activated to control the infection. To be beneficial for the host, the production of NO must be tightly 
regulated to exert antiviral rather than harmful effects, such as cell death and tissue destruction. This regulation of NO production could be at the transcriptional and the translational level but also at the level of enzyme activity during infection, as was demonstrated in a mouse-Cryptococcus neoformans model (21). At present, it is unclear whether the level of in vivosynthesized NO compares to the level of NO released from NO donors in vitro. Only recently, limited information has become available on the induction of NO after respiratory virus infections, including influenza $(17,23)$. The contribution of NO to the pathogenesis of influenza virus-induced pneumonia of mice $(2,16)$ was also observed in HSV-1-induced pneumonia in this species (1). However, a clear antiviral effect of NO was also demonstrated against the latter virus in vitro $(6,15)$. This pathological effect of NO in virus-induced pneumonia may be specific for mouse models for pneumonia, since the peak of exhaled NO in experimentally infected humans was not associated with the clinical symptoms of these individuals (23).

We thank Conny Kruyssen for handling of the manuscript, Ger van der Water for continuous support, and Theo Bestebroer for excellent technical assistance.

This work was supported by the Foundation for Respiratory Virus Infections notably Influenza (SRVI).

\section{REFERENCES}

1. Adler, H., J. L. Beland, N. C. Del-Pan, L. Kobzik, J. P. Brewer, T. R. Martin, and I. J. Rimm. 1997. Suppression of herpes simplex virus type 1 (HSV-1)induced pneumonia in mice by inhibition of inducible nitric oxide synthase (iNOS, NOS2). J. Exp. Med. 185:1533-1540.

2. Akaike, T., Y. Noguchi, S. Ijiri, K. Setoguchi, M. Suga, Y. M. Zheng, B. Dietzschold, and H. Maeda. 1996. Pathogenesis of influenza virus induced pneumonia: involvement of both nitric oxide and oxygen radicals. Proc. Natl. Acad. Sci. USA 93:2448-2453.

3. Akarid, K., M. Sinet, B. Desforges, and M. A. Gougerot-Pocidalo. 1995. Inhibitory effect of nitric oxide on the replication of a murine retrovirus in vitro and in vivo. J. Virol. 69:7001-7005.

4. Asano, K., C. B. E. Chee, B. Gaston, C. M. Lilly, C. Gerard, J. M. Drazen, and J. S. Stamler. 1994. Constitutive and inducible nitric oxide synthase gene expression, regulation and activity in human lung epithelial cells. Proc. Natl. Acad. Sci. USA 91:10089-10093.

5. Bi, Z., and C. S. Reiss. 1995. Inhibition of vesicular stomatitis virus infection by nitric oxide. J. Virol. 69:2208-2213.

6. Croen, K. 1993. Evidence for an antiviral effect of nitric oxide. Inhibition of herpes simplex type 1 replication. J. Clin. Investig. 91:2446-2452.

7. Geller, D. A., C. J. Lowenstein, R. A. Shapiro, A. K. Nussler, M. Di Silvio, S. C. Wang, D. K. Nakayama, R. L. Simmons, S. H. Snyder, and T. R. Billiar. 1993. Molecular cloning and expression of inducible nitric oxide synthase from human hepatocytes. Proc. Natl. Acad. Sci. USA 90:3491-3495.

8. Green, L. A., D. A. Wagner, J. Glogowski, P. L. Skipper, J. S. Wishnol, and S. R. Tannenbaum. 1982. Analysis of nitrate, nitrite and [15N]nitrate in biological fluids. Anal. Biochem. 1256:131.

9. Gunning, P., P. Ponte, H. Okayama, J. Engel, H. Blau, and L. Kedes. 1983. Isolation and characterization of full-length cDNA clones for human $\alpha-, \beta-$, and $\gamma$-actin mRNAs: skeletal but not cytoplasmic actins have an aminoterminal cysteine that is subsequently removed. Mol. Cell. Biol. 3:787-795.

10. Guo, F. H., H. R. De Raeve, T. W. Rice, D. J. Stuehr, F. B. J. M. Thunnissen, and S. C. Erzurum. 1995. Continuous nitric oxide synthesis by inducible nitric oxide synthase in normal human airway epithelium in vivo. Proc. Natl. Acad. Sci. USA 92:7809-7813.

11. Harris, N., R. M. L. Buller, and G. Karupiah. 1995. Gamma interferoninduced nitric oxide-mediated inhibition of vaccinia virus replication. J. Virol. 69:910-915.

12. Hayden, F. G., R. S. Fritz, M. C. Lobo, W. G. Alvord, W. Strobe, and S. E. Straus. 1998. Local and systemic cytokine responses during experimental human influenza A virus infection. J. Clin. Investig. 101:643-649.

13. Hennet, T., H. J. Ziltener, K. Frei, and E. Peterans. 1992. A kinetic study of immune mediators in the lungs of mice infected with influenza A virus. J. Immunol. 149:932-939.

14. Ignarro, L. J., H. Lippton, J. C. Edwards, W. H. Baricos, A. L. Hyman, P. J. Kadowitz, and C. A. Gruetter. 1981. Mechanism of vascular smooth muscle relaxation by organic nitrates, nitrites, nitroprusside and nitric oxide: evi- dence for the involvement of S-nitrosothiols as active intermediates. J. Pharm. Exp. Ther. 218:739-749.

15. Karupiah, G., Q. W. Xie, R. M. L. Buller, C. Nathan, C. Duarte, and J. D. MacMicking. 1993. Inhibition of viral replication by interferon-gamma-induced nitric oxide synthase. Science 261:1612-1615.

16. Karupiah, G., J.-H. Chen, S. Mahalingam, C. F. Nathan, and J. D. MacMicking. 1998. Rapid interferon $\gamma$-dependent clearance of influenza A virus and protection from consolidating pneumonitis in nitric oxide synthase 2-deficient mice. J. Exp. Med. 188:1541-1546.

17. Kharitonov, S. A., D. Yates, P. J. Barnes. 1995. Increased nitric oxide in exhaled air of normal human subjects with upper respiratory tract infections. Eur. Respir. J. 8:295-297.

18. Lancaster, J. R., Jr., and J. B. Hibbs, Jr. 1990. EPR demonstration of iron-nitrosyl complex formation by cytotoxic activated macrophages. Proc. Natl. Acad. Sci. USA 87:1223-1227.

19. Lin, Y.-L., Y.-L. Huang, S.-H. Ma, C.-T. Yeh, S.-Y. Chiou, L.-K. Chen, and C.-L. Liao. 1997. Inhibition of Japanese encephalitis virus infection by nitric oxide: antiviral effect of nitric oxide on RNA virus replication. J. Virol. 71:5227-5235.

20. Lopez-Guerrero, J. A., and L. Carrasco. 1998. Effect of nitric oxide on poliovirus infection of two human cell lines. J. Virol. 72:2538-2540.

21. Lovchik, J., M. Lipscomb, and R. C. Lyons. 1997. Expression of lung inducible nitric oxide synthase protein does not correlate with nitric oxide production in vivo in a pulmonary immune response against cryptococcus neoformans. J. Immunol. 158:1772-1778.

22. Mannick, J. B. 1998. The antiviral role of nitric oxide. Free Radic. Biol. Med. 25:693-697.

23. Murphy, A. W., T. A. E. Platts-Mills, M. Lobo, and F. Hayden. 1998. Respiratory nitric oxide levels in experimental human influenza. Chest 114:452 456.

24. Nathan, C. F., and J. B. Hibbs, Jr. 1991. Role of nitric oxide synthesis in macrophage antimicrobial activity. Curr. Opin. Immunol. 3:65-70.

25. Nathan, C. 1992. Nitric oxide as a secretory product of mammalian cells. FASEB J. 6:3051-3064

26. Nicholson, S., M. da G. Bonecini-Almeida, J. R. Lape e Silva, C. Nathan, Q.-W. Xie, R. Mumford, J. R. Weidner, J. Calaycay, J. Geng, N. Boechat, C. Linhares, W. Rom, and J. L. Ho. 1996. Inducible nitric oxide synthase in pulmonary alveolar macrophages from patients with tuberculosis. J. Exp. Med. 183:2293-2302.

27. Pahl, H. L., and P. A. Baeuerle. 1995. Expression of influenza virus hemagglutinin activates transcription factor NF-кB. J. Virol. 69:1480-1484.

28. Pellat, C., Y. Henry, and J.-C. Drapier. 1990. IFN- $\gamma$-activated macrophages: detection by electron paramagnetic resonance of complexes between L-arginine derived nitric oxide and non-home iron proteins. Biochem. Biophys. Res. Commun. 166:119-125.

29. Pope, M., P. A. Marsden, S. Sloan, L. S. Fung, Q. Ning, J. W. Ding, J. L. Leibowitz, M. J. Phillips, and G. A. Levy. 1998. Resistance to murine hepatitis virus strain 3 is dependent on production of nitric oxide. J. Virol. 72:7084-7090.

30. Rimmelzwaan, G. F., M. Baars, E. C. J. Claas, and A. D. M. E. Osterhaus. 1998. Comparison of RNA hybridization, hemagglutination assay, titration of infectious virus and immunofluorescence as methods for monitoring influenza virus replication in vitro. J. Virol. Methods 74:57-66.

31. Sanders, S. P., P. E. S. Sierkierski, J. D. Porter, S. M. Richards, and D. Proud. 1998. Nitric oxide inhibits rhinovirus-induced cytokine production and viral replication in a human respiratory epithelial cell line. J. Virol. 72:934-942.

32. Sarawar, S. R., and P. C. Doherty. 1994. Concurrent production of interleukin-2, interleukin-10, and gamma interferon in the regional lymph nodes of mice with influenza pneumonia. J. Virol. 68:3112-3119.

33. Sharara, A. I., D. J. Perkins, M. A. Misukonis, S. U. Chan, J. A. Dominitz, and J. B. Weinberg. 1997. Interferon (IFN)- $\alpha$ activation of human blood mononuclear cells in vitro and in vivo for nitric oxide synthase (NOS) type 2 mRNA and protein expression: possible relationship of induced NOS2 to the antihepatitis C effects of IFN- $\alpha$ in vivo. J. Exp. Med. 186:1495-1502.

34. Sprenger, H., M. Bacher, E. Rischowsky, A. Bender, M. Nain, and D. Gemsa. 1994. Characterization of a high molecular weight tumor necrosis factor- $\alpha$ mRNA in influenza A virus-infected macrophages. J. Immunol. 152:280-289.

35. Taylor-Robinson, A. W., F. Y. Liew, A. Severn, D. Xu, S. J. McSorley, P. Garside, J. Padron, and R. S. Phillips. 1994. Regulation of the immune response by nitric oxide differentially produced by $\mathrm{T}$ helper type 1 and $\mathrm{T}$ helper type 2 cells. Eur. J. Immunol. 24:980-984.

36. Xie, Q. W., H. J. Cho, J. Calaycay, R. A. Mumford, K. M. Swiderek, T. D. Lee, A. Ding, T. Troso, and C. Nathan. 1992. Cloning and characterization of inducible nitric oxide from mouse macrophages. Science 256:225-228.

37. Zaragoza, C., C. J. Ocampo, M. Saura, A. McMillan, and C. J. Lowenstein. 1997. Nitric oxide inhibition of coxsackie virus replication in vitro. J. Clin. Investig. 100:1760-1767. 